\title{
Response of Soil Microorganisms, Nitrogenase Activity and Growth of Onion Plants to the Interaction between Glomus mosseae and Azotobacter chroococcumre
}

\author{
Yaser Ayesh AlMaroai ${ }^{1,2}$ (D) \\ ${ }^{1}$ Department of Biology, Faculty of Applied Science, Umm Al-Qura University, Makkah 21421, \\ Saudi Arabia. ${ }^{2}$ Research Laboratories Centre, Faculty of Applied Science, Umm Al-Qura University, \\ Makkah, Saudi Arabia.
}

\begin{abstract}
A greenhouse nursery study was conducted to assess the interactive effects of arbuscular mycorrhizal (AM) fungus (Glomus mosseae) and nitrogen-fixing bacteria (Azotobacter chroococcum) on leading microorganisms group, growth, and nutrition of onion plants grown in unsterile calcareous soil in a greenhouse pot experiment. The results showed that Glomus mosseae and Azotobacter chroococcum significantly $(\mathrm{P}=0.05)$ increased bacterial, actinomycetes, Azotobacter count, and nitrogenase activity in onion rhizosphere. Moreover, coupling both organisms significantly increased sporulation and mycorrhizal infection of onion plant roots. Dry weight, nitrogen, and phosphorus uptake of shoots of dually inoculated plants were far higher than of shoots of plants inoculated with either microorganisms. It could conclude that microbial soil co-inoculation Glomus mosseae and Azotobacter chroococcum significantly enhance plant growth, $\mathrm{N}$ and $\mathrm{P}$ uptake of onion, and the strategy may be applied to obtain better crop productivity.
\end{abstract}

Keywords: Inoculation; Arbuscular Mycorrhizal; Nitrogen fixation; Rhizosphere microflora; Nirtogenase activity.

*Correspondence: Yamarwei@uqu.edu.sa; +966 555513837

(Received: 03 June 2019; accepted: 22 July 2019)

Citation: Yaser Ayesh AlMaroai, Response of Soil Microorganisms, Nitrogenase Activity and Growth of Onion Plants to the Interaction between Glomus mosseae and Azotobacter chroococcumre, J Pure App/ Microbiol., 2019; 13(4):2087-2095. https:// doi.org/10.22207/JPAM.13.4.20

(C) The Author(s) 2019. Open Access. This article is distributed under the terms of the Creative Commons Attribution 4.0 International License which permits unrestricted use, sharing, distribution, and reproduction in any medium, provided you give appropriate credit to the original author(s) and the source, provide a link to the Creative Commons license, and indicate if changes were made. 


\section{INTRODUCTION}

The mycorrhizal fungi on plant development effects have known, and inoculation with these microorganisms is considered an effective method for the improved ability of plants to cope with harmful soil conditions. However, the co-inoculations of mycorrhizal fungi and other rhizosphere inhabitants into soil can be damaging to the mycorrhizal fungi and certain rhizosphere microorganisms ${ }^{1}$. Interactions between mycorrhizal fungi and other soil microorganisms may occur widely. Shifts in the presence or abundance of microbial species occur in the rhizosphere of mycorrhizal plants ${ }^{2}$. Rhizobacteria can affect plant growth according to the environmental conditions, host genotype and mycorrhizal status ${ }^{3,4}$. Their effects range from promoting the development some of the plant organs to inhibiting others simultaneously ${ }^{5}$. Similarly, rhizobacteria can stimulate ${ }^{6}$ or inhibit ${ }^{7}$ mycorrhizal formation. The AM fungi also may increase $^{8}$ or decrease ${ }^{9}$ soil bacterial population in the mycorrhizosphere. On the other hand, mycorrhizal fungi exert profound effects on other rhizosphere microorganisms, either through indirect effects on host physiology and changes in root exudates or directly via fungal exudates ${ }^{3}$.

Seed inoculation with rhizobacteria may also stimulate the infection of roots by the indigenous VAM community. Behl ${ }^{3}$ and Sharma ${ }^{10}$ reported synergistic effects between Azotobacter and Glomu. A large number of bacterial populations (including actinomycetes) have recovered from either individual or the various rhizosphere combinations of tomato plants inoculated with the mycorrhizal fungus Glomus fasciculatus and Azotobacter chroococcum ${ }^{11}$. Plants inoculated with both $G$. fasciculatus and A. chroococcum had greater numbers of bacteria and actinomycetes in the rhizosphere than plants inoculated with either G. fasciculatus or A. chroococcum alone. Behl12 observed similar effects of inoculation on the bacterial population in wheat. Brown and Carr ${ }^{13}$ found that dual inoculation of roots of lettuce seedlings with AM fungi and $A$. chroococcum produced larger plants than either inoculum alone in the partially sterilized, P deficient soil. Singh (1992) found that inoculation of $\mathrm{N}_{2}$ - fixing (Azospirillum brasilense, A. lipoferum, and Azotobacter chroococcum) and P solubilizing
(Bacillus polymyxa and Pseudomonas striata) bacteria enhanced root volume and percent VAM root colonization of Pennisetum padicillatum in the presence of Glomus macrocarpum. It was also found in this study that inoculation with these tow groups of bacterial resulted in increased number of VAM spores.

The current work aims to investigate the response of main soil microorganisms (bacteria, actinomycetes and fungi) to soil inoculation with mycorrhizal fungus Glomus mosseae and Azotobacter chroococcum in the rhizosphere of onion plant. Besides, the interactions between these organisms and their effect on plant growth and nutrition explored.

\section{MATERIALS AND METHODS}

\section{Preparation of microbial inoculums}

The arbuscular mycorrhizal inoculum consisted of the root, hyphal, spores, and growth media from a pot culture of onion plants, which previously infected with Glomus mosseae grown for 4 months in pot. The inoculum contained 250 spores/g soils together with mycelium and mycorrhizal root fragments that used. At rate of $5 \mathrm{~g} /$ pot $^{14}$. The number of spores in the soil sample determined by the wet sieving method ${ }^{15}$. Mycorrhizal inoculation completed by spreading the inoculum on the surface of the soil prior to seed sowing.

Azotobacter chroococcum (non-symbiotic nitrogen fixation) gained from the Faculty of Agriculture, Soils and Water Department., Assiut University, Egypt, which supplies a commercial scale biofertilizer called "Azotobactrien." The strain

Table 1. Physical and chemical characteristics of soil used in the experiment

\begin{tabular}{lc}
\hline Soil Property & Values \\
\hline Clay (\%) & 9.3 \\
Silt (\%) & 30.5 \\
Sand (\%) & 60.2 \\
Textural class & Sandy loam \\
Total $\mathrm{CaCO}_{3}(\%)$ & 16.18 \\
$\mathrm{EC} \mathrm{dS} / \mathrm{cm}^{-1}(1: 1)$ & 1.22 \\
$\mathrm{pH}\left(1: 1\right.$ suspension) $^{\text {Total nitrogen (\%) }}$ & 7.82 \\
Organic matter (\%) & 0.04 \\
Available P mg g ${ }^{-1}$ soil & 0.30 \\
\hline
\end{tabular}


was grown on nutrient agar at $28 \div \mathrm{C}$ for $72 \mathrm{hr}$. The massive growth bacterial cultures scraped into sterile tap water to give a suspension containing $1.7 \times 10^{7}$ cells $/ \mathrm{ml}$. Five $\mathrm{ml}$ of this suspension added per pot during planting ${ }^{16}$.

\section{Greenhouse experiment}

The trial was carried out within an automated day-night temperature-controlled environment of the Greenhouse of Biology Department, Faculty of Applied Science, Umm AlQura University, Saudi Arabia. A pot experiment was conducted in 2016 season to study the interactions between the arbuscular mycorrhizal fungus, Glomus mosseae, and Azotobacter chroococcum and their effects on onion plants in calcareous soil. Some physical and chemical properties of soil used in the experiment presented in Table 1, measured according to Page et al. ${ }^{17}$. The experimental design used a completely randomized block design by employing four treatments with four replications of each treatment. The treatments included: uninoculated control (C); inoculation with AM fungus (Glomus mosseae) (Gm); inoculation with Azotobacter chroococcum (Azot); mixed inoculation with Glomus mosseae and Azotobacter chroococcum (Gm + Azot).

Three Seedlings of onion (Allim cepa L.) cultivar Giza-6 were planted in $30 \mathrm{~cm}$ diameter plastic pots containing $5 \mathrm{~kg}$ sieved calcareous soil. The pots irrigated to field capacity $(47 \%)$ during the experimental period under greenhouse condition. After two weeks post planted, the seedlings thinned to two uniform plants per pot.

\section{Microbial determination}

Plants were harvested 20 and 40 days after planting. At each harvest, part of the root system of each 4 replicates, was cleaned with a stream of tap water, cleared in $2.5 \% \mathrm{KOH}$ at $90 \div \mathrm{C}$ and stained with trypan blue $(0.05 \%)$ was used for staining as described by ${ }^{18}$ and the percent root colonization estimated by adopting the gridline intersect method $^{19}$. The total bacteria, actinomycetes, and fungi population were estimated using soil extract agar, starch casein agar, and Czapek agar medium, respectively, whereas Azotobacter estimated on Ashby's Mannitol Agar medium ${ }^{20}$.

\section{Nitrogenase activity assay}

Nitrogenase activity of the rhizosphere soil microorganisms was assayed using the acetylene reduction technique ${ }^{21}$. Briefly, $1 \mathrm{~g}$ rhizosphere soil was placed immediately in a canning jar fitted with a serum stopper for gas sampling. Ten percent of the gaseous atmosphere in the jar was removed and replaced by acetylene $\left(\mathrm{C}_{2} \mathrm{H}_{2}\right)$. The jars were then tightly sealed with parafilm and incubated at $30^{\circ} \mathrm{C}$ for $24 \mathrm{~h}$. A volume of $0.1 \mathrm{ml}$ gas sample from each jar was removed and injected into a Pye Unicome 104 inch gas chromatograph containing a flame ionization detector and a $5 \mathrm{Ft}$. X 118-inch glass column of activated alumina (80-100 mesh). The oven temperature was $150^{\circ} \mathrm{C}$, and the carrier gas was nitrogen at a flow rate of $30 \mathrm{ml} / \mathrm{min}$.

\section{Plant analyses}

Plants were harvested 20 and 40 days after planting. Shoot biomass determined after drying the plant samples to constant weight at $70^{\circ} \mathrm{C}$ in a

Table 2. Microbial population of onion rhizosphere as influenced by inoculation with Glomus moseae and Azotobacter chroococcum, 20 and 40 days after planting (DAS)

\begin{tabular}{|c|c|c|c|c|c|c|}
\hline \multirow[t]{2}{*}{ Treatments } & \multicolumn{2}{|c|}{$\begin{array}{c}\text { Bacterial } \\
\text { population } \\
\left(10^{7} / \mathrm{g} \text { dry soil) }\right.\end{array}$} & \multicolumn{2}{|c|}{$\begin{array}{l}\text { Actinomycetes } \\
\text { population } \\
\left(10^{6} / \mathrm{g} \text { dry soil) }\right.\end{array}$} & \multicolumn{2}{|c|}{$\begin{array}{l}\text { Fungal } \\
\text { population } \\
\left(10^{3} / g \text { dry soil) }\right.\end{array}$} \\
\hline & 20 DAS & 40 DAS & 20 DAS & 40 DAS & 20 DAS & 40 DAS \\
\hline$C$ & $0.9 \pm 1.3$ & $4.1 \pm 1.5$ & $2.3 \pm 1.2$ & $5.4 \pm 1.6$ & $3.3 \pm 1.9$ & $5.1 \pm 1.4$ \\
\hline Azoto. & $1.2 \pm 1.2$ & $5.4 \pm 1.3$ & $3.6 \pm 1.4$ & $7.1 \pm 1.3$ & $3.8 \pm 2.0$ & $5.7 \pm 1.7$ \\
\hline $\mathrm{Gm}$ & $1.4 \pm 1.6$ & $5.9 \pm 1.8$ & $4.2 \pm 1.5$ & $8.0 \pm 1.3$ & $1.9 \pm 1.6$ & $2.8 \pm 1.5$ \\
\hline Azoto.+Gm & $1.9 \pm 1.3$ & $6.3 \pm 1.5$ & $5.2 \pm 1.6$ & $10.2 \pm 1.6$ & $2.2 \pm 1.8$ & $3.1 \pm 1.5$ \\
\hline L.S.D. $5 \%$ & $0.2 \pm 1.4$ & $0.3 \pm 1.5$ & $1.1 \pm 1.7$ & $1.4 \pm 1.5$ & $0.9 \pm 1.6$ & $1.1 \pm 1.6$ \\
\hline
\end{tabular}

C: uninoculated control

Azoto.: inoculated with Azotobacter chroococcum.

$\mathrm{Gm}$ : inoculated with Glomus moseae. 
hot air oven. The nitrogen content of shoot that determined by microKjeldhal method as outlined by Jackson ${ }^{22}$. The phosphorus content of shoot and root determined by the vanadomolybdate phosphoric yellow color method ${ }^{22}$.

\section{Statistical analysis}

The data reported in this paper were the mean values based on the four replications. Differences among treatments were tested by ANOVA and mean values among treatments were compared by Duncan's Multiple Range Test at $P=$ 0.05 . Statistical analysis of the data was performed by using the statistical computer program ${ }^{23}$.

\section{RESULTS AND DISCUSSION}

\section{Effect on soil microorganisms population}

Inoculation of onion plants with arbuscular mycorrhizal fungus G. mosseae or Azotobacter chroococcum significantly increased bacterial and actinomycetes numbers in the rhizosphere after 20 and 40 days (Table 2). Dual inoculation with both organisms highly significantly $(P=0.05)$ increased rhizosphere bacteria or actinomycetes numbers. In the meantime, the fungal population in the rhizosphere was non-significantly increased in the presence of Azotobacter alone, whereas in the presence of G. mosseae alone or coupled with

D20 DAS $\square 40 \mathrm{DAS}$

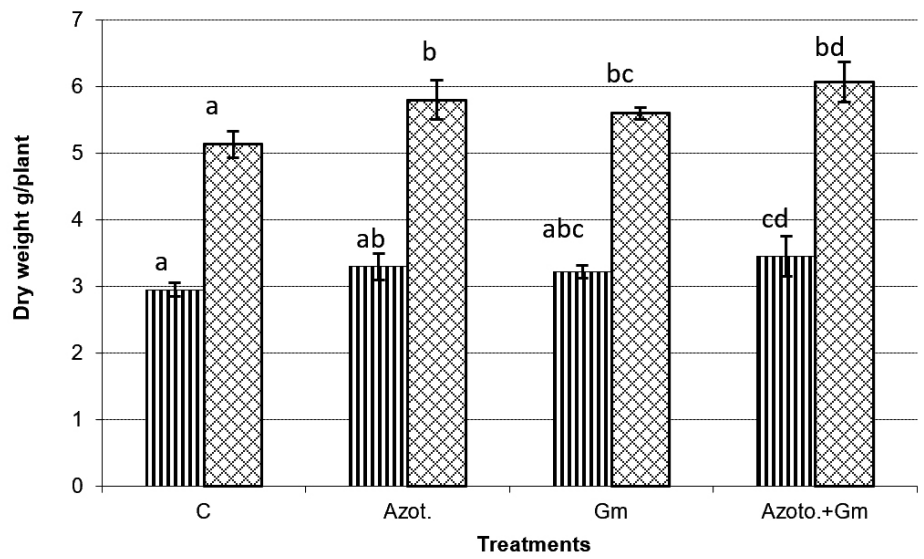

Fig. 1. Dry weight of onion plants as influenced by inoculation with Glomus moseae (Gm) and Azotobacter chroococcum (Azoto.), 20 and 40 days after planting (DAS).

Table 3. Population of Azotobacter and nitrogenase activity in onion rhizosphere as influenced by inoculation with Glomus moseae and Azotobacter chroococcum, 20 and 40 days after planting (DAS)

\begin{tabular}{|c|c|c|c|c|}
\hline \multirow[t]{2}{*}{ Treatments } & \multicolumn{2}{|c|}{$\begin{array}{l}\text { Azotobacter } \\
\text { population } \\
\left(10^{4} / g \text { dry soil) }\right.\end{array}$} & \multicolumn{2}{|c|}{$\begin{array}{c}\text { Nitrogenase } \\
\text { activity } \\
\text { (nmol } \mathrm{C}_{2} \mathrm{H}_{2} / \text { g soil/hour) } \\
\end{array}$} \\
\hline & 20 DAS & 40 DAS & 20 DAS & $40 \mathrm{DAS}$ \\
\hline C & $0.25 \pm 1.2$ & $0.97 \pm 1.1$ & $10.30 \pm 0.3$ & $26.22 \pm 0.3$ \\
\hline Azoto. & $5.12 \pm 0.9$ & $12.70 \pm 1.4$ & $90.14 \pm 0.1$ & $182.85 \pm 0.4$ \\
\hline $\mathrm{Gm}$ & $0.48 \pm 1.5$ & $2.10 \pm 0.9$ & $13.78 \pm 0.2$ & $52.15 \pm 0.2$ \\
\hline Azoto.+Gm & $10.25 \pm 1.2$ & $25.90 \pm 1.3$ & $114.02 \pm 0.3$ & $220.90 \pm 0.1$ \\
\hline L.S.D. 5 \% & $0.95 \pm 0.7$ & $1.82 \pm 1.2$ & $7.35 \pm 0.2$ & $18.20 \pm 0.2$ \\
\hline
\end{tabular}

C: Uninoculated (control).

Azoto.: Inoculated with Azotobacter chroococcum.

$\mathrm{Gm}$ : Inoculated with Glomus moseae. 
Azotobacter, the fungal count highly significantly dropped; more prominently during the first sample period.

The results of the current investigation apparently indicate that inoculation of onion plants with mycorrhizal fungus $G$. mosseae or Azotobacter chroococcum stimulated bacterial and actinomycetes multiplication though the former attenuated fungal development in the rhizosphere of the plant. Application of both organisms enhanced their stimulatory effect and slightly alleviated the suppressive impact of $G$. mosseae on fungal population. In the presence of Azotobacter, the net bacterial count (by subtracting the native control count) of the second sampling was almost 4 folds that of the first, whereas in the presence of mycorrhizal fungus $G$. mosseae it was only 3 fold. Dual inoculation only doubled the population density during the second sampling. The present result indicated that the stimulatory effect of Azotobacter is higher than that of mycorrhizal fungus $G$. mosseae. The observed changes in the population of the microorganisms can attribute to the ability of mycorrhiza-forming fungi to brought about several alterations in the rhizosphere. These include production of biologically active metabolites, decreased oxygen concentration, and modification of the composition and amount

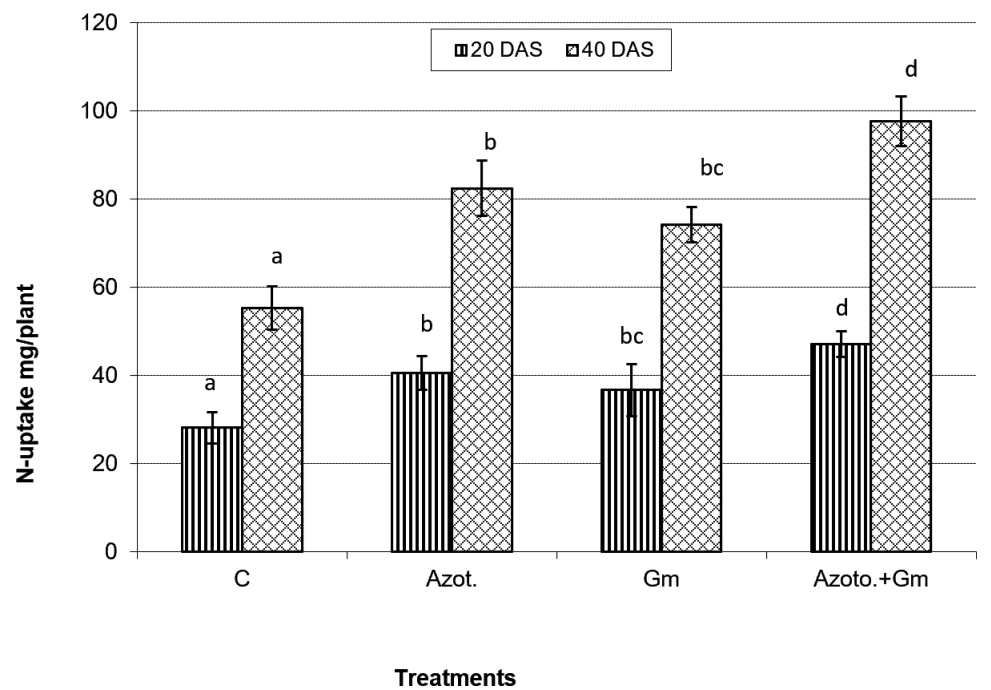

Fig. 2. Nitrogen uptake of onion plants as influenced by inoculation with Glomus moseae (Gm) and Azotobacter chroococcum (Azoto.), 20 and 40 days after planting (DAS).

Table 4. Mycorrhizal spores in soil and percentage mycorrhizal infection of onion roots as influenced by inoculation with Glomus moseae and Azotobacter chroococcum, 20 and 40 days after planting (DAS)

\begin{tabular}{|c|c|c|c|c|}
\hline \multirow[t]{2}{*}{ Treatments } & \multicolumn{2}{|c|}{$\begin{array}{l}\text { Mycorrhizal } \\
\text { spores/10 g dry soil }\end{array}$} & \multicolumn{2}{|c|}{$\begin{array}{l}\text { Mycorrhizal } \\
\text { infection (\%) }\end{array}$} \\
\hline & 20 DAS & 40 DAS & 20 DAS & 40 DAS \\
\hline C & $11.30 \pm 3.2$ & $13.12 \pm 6.2$ & $17 \pm 7.4$ & $20 \pm 6.5$ \\
\hline Azoto. & $15.50 \pm 5.1$ & $19.45 \pm 5.8$ & $20 \pm 6.5$ & $22 \pm 7.1$ \\
\hline $\mathrm{Gm}$ & $37.11 \pm 4.9$ & $40.30 \pm 4.6$ & $65 \pm 4.8$ & $67 \pm 7.8$ \\
\hline Azoto.+Gm & $40.50 \pm 5.3$ & $45.73 \pm 4.9$ & $68 \pm 8.0$ & $70 \pm 6.4$ \\
\hline L.S.D. 5 \% & $4.40 \pm 3.8$ & $5.25 \pm 5.3$ & $6.33 \pm 5.3$ & $7.11 \pm 7.0$ \\
\hline
\end{tabular}

C: uninoculated (control).

Azoto.: Inoculated with Azotobacter chroococcum.

$\mathrm{Gm}$ : Inoculated with Glomus moseae 
of plant root exudates or the extradical mycelium of AM fungi, which occupies a far higher volume of soil than roots and influence the chemical composition and $\mathrm{pH}$ of the soil ${ }^{24}$. Accordingly, the impact of mycorrhiza-forming fungi on microorganism populations could be significantly synergistic or antagonistics with the influence of root exudates. Additional, it is possible that AM fungi release non-soluble and/or volatile substances that can affect soil microorganisms ${ }^{25}$.

In this respect, Sood ${ }^{26}$ reported an increase in bacteria actinomycetes and dinitrogen fixing bacteria "Azotobacter" number in unsterile soil due to mycorrhizal fungi infection. In contrast, Meyer and Linderman ${ }^{27}$ observed that infection with mycorrhiza fungus reduced the multiplication of Streptomyces sp. McAllister et al. ${ }^{28}$ reported that mycorrhizal fungus $G$. mosseae reduced the saprophytic fungal population in the rhizosphere of maize and lettuce plants. Single and dual inoculation of wheat seedlings with Azotobacter chroococcum, Azospirillum brasilence or Streptomyces mutobilis, in sterilized soil, resulted in a significant stimulation of their population in the rhizosphere ${ }^{29}$. Two possible effects suggested by Behl et al. ${ }^{3}$ for the stimulating effect of Azotobacter on mycorrhiza are: 1) if absorbed into the roots, it can directly enhance of the metabolic activity of the mycorrhiza, or 2) the increasing leaf size could enhance the potential for photo-synthesizing nutrient supplies for the endophytes within the plants.

\section{Effect of Azotobacter and mycorrhizal population} and nitrogenase activity

Mycorrhizal inoculation increased the Azotobacter population in both inoculated and unionculated rhizosphere soil, and stimulated nitrogenase activity in onion rhizosphere, more prominently during the second sampling (Table 3). Azotobacter count mostly doubled when it combined with $G$. mosseae whereas nitrogenase activity stimulated by 1.2-1.3 fold. Table 4 shows that Azotobacter significantly $(\mathrm{P}=0.05)$ increased the spore number and infection percent of onion plants by native mycorrhiza. The same applied when Azotobacter was inoculated together with G. mosseae, where neither the spore count of the latter nor its infection percent significantly altered. Also, inoculation with mycorrhizal fungus $G$. mosseae increased the spore number and mycorrhizal infection to 3 fold or more compared with uninoculated treatments. That's invistegation confirms the synergistic effect both organisms. Inoculation with Azotobacter seemed to increase the sporulation and mycorrhizal infection in the onion plant. It might attribute to the production of growth-promoting substances by the dinitrogen fixing bacteria. Behl et al. ${ }^{3}$ suggested that the increased mycorrhizal infection and sporulation due to phospho-bacteria or dinitrogen fixing

\section{m20 DAS $\square 40$ DAS}

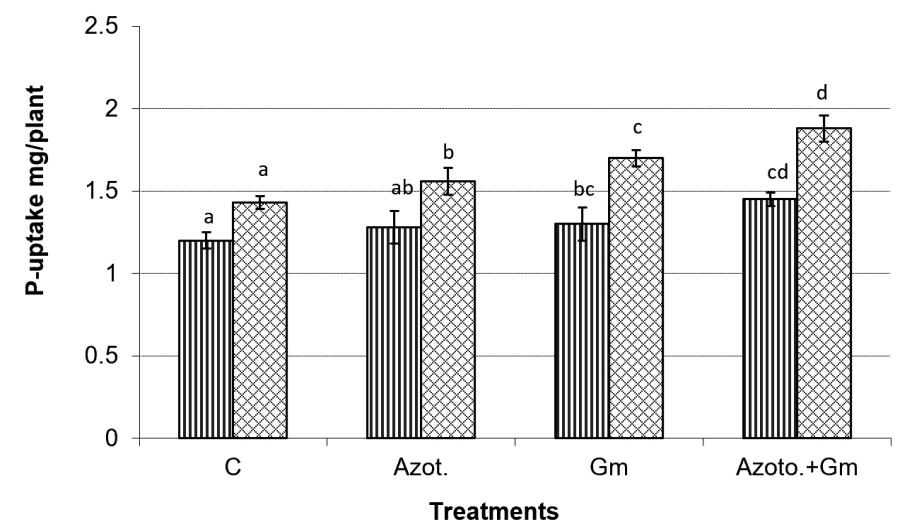

Fig. 3. Phosphorus uptake of onion plants as influenced by inoculation with Glomus moseae $(\mathrm{Gm})$ and Azotobacter chroococcum (Azoto.), 20 and 40 days after planting (DAS). 
bacteria in the rhizosphere might be due to the production of plant growth substances by these bacteria. Tilak and Dwivedi ${ }^{30}$ reported the excretion of auxins, cytokinins, and gibberellins in the rhizosphere of maize plants by Azospirillum brasilense stimulated spore germination of AM fungus Glomus fasciculatum.

Dinitrogen fixing bacteria in the rhizosphere can contribute to the supply of nitrogen in the soil, which improved plant development. The beneficial effects of Azotobacter on plant growth and nitrogen uptake by plant might be through nitrogen fixation ${ }^{31}$ or growth promoting substances ${ }^{32}$.

\section{Effect on dry weight, $\mathbf{N}$ and $\mathbf{P}$ uptake}

Onion dry weight was significantly $(P=0.05)$ increased by inoculation with either of the two organisms, a response that was hardly affected by dual inoculation of both organisms (Fig.1). The nitrogen uptake of onion plants increased with the progress of age, with Azotobacter inoculation being significantly more initiative than inoculation with mycorrhizal fungus $G$. mosseae, whereas their dual application furthered such effect (Fig.2). Phosphorus uptake behaved even though if the presence of mycorrhizal fungus $G$. mosseae alone or coupled with Azotobacter stimulated its uptake, more prominently under the latter condition, without affecting the efficacy of mycorrhizal fungus G. mosseae (Fig.3). The current result confirms the additive beneficial effects of both organisms. Manske et al. ${ }^{31}$ reported that the degree of root colonization varied not only with different Plant growth-promoting rhizobacteria (PGPR) species but also with different isolates in some IAA producing PGPRs which enhanced sporulation of VAM fungi by $45 \%$. Glomus fasciculatum and Azotobacter chroococcum inoculation increased the $\mathrm{P}$ concentration in wheat shoots at tillering. Wu et $a .^{33}$ evaluated the effects of four biofertilizers containing an arbuscular mycorrhizal fungus (G. mosseae or G. intraradices) with or without $\mathrm{N}_{2}$-fixer (A. chroococcum), P-solubilizer (Bacillus megaterium) and K-solubilizer (B. mucilaginous) on soil features and the growth of Zea mays. The application of biofertilizer containing AMF and three species of bacteria significantly increased the growth of Zea mays, nutrients assimilation of the plant (total N, P and K), and soil properties.

Triple inoculation of Glomus. geosporum,
Azotobacter chroococcum, and Bacillus coagulans resulted in maximum plant biomass, $\mathrm{N}, \mathrm{P}, \mathrm{Zn}$, and $\mathrm{Cu}$ uptake, and biovolume and quality index of Melia azedarach L.seedlings. It also increased the mycorrhizal root colonization and spore numbers in the root zone soil of the inoculated plants over uninoculated control plants. The enzyme activity, namely acid phosphatase and dehydrogenase, in the root zone soil, was found high in the 3-combination treatments and low in the uninoculated control ${ }^{33}$.

Yousefi et al. ${ }^{34}$ found that combined application of phosphate solubilizing bacteria (PSB) and arbuscular mycorrhizal fungi increased shoot dry matter yield, seed grain spike number and grain yield by 52, 19 and 26\%, respectively compared to the control. Vafadar et al. ${ }^{35}$ reported that stevioside, chlorophyll, and NPK content in plants increased root and shoot biomass by a single microorganism. However, such increased effects are further enhanced significantly due to dual compatible mixtures of inoculants resulting from their strong synergistic relationships among themselves. All growth parameters recorded the highest in 60-days-old plants in the treatment of Glomus + Azotobacter and followed with Glomus + Bacillus and Azotobacter + Pseudomonas treatments, respectively. Kumar et al. ${ }^{36}$ found that a significant improvement in the shoot height, shoot diameter, fruit yield/plant, and seed yield (g)/plant was evident in 18-month-old Jatropha plants under field conditions when Azotobacter and AMF were co-inoculated.

\section{CONCLUSION}

The results showed that Azotobacter chroococcum and Arbuscular mycorrhizal fungus (Glomus mosseae) exhibited positive mutual relationships. Dual inoculation of onion with Azotobacter and AM fungi increased bacterial and actinomycetes numbers, nitrogenase activity in onion rhizosphere, dry weight, N, and P uptake. Accordingly soil inoculation with these microorganisms participated in better growth of onion plants and may be applied to other crop plants for better growth, thereby helping to reduce the industrial application of fertilizers and alleviate environmental pollution. Further research is required to investigate these microorganisms under field conditions. 


\section{ACKNOWLEDGEMENTS}

The author would like to thank College of Sciences, Umm Al-Qura University, Kingdom of Saudi Arabia for supporting his study.

\section{FUNDING}

None.

\section{DATA AVAILABILITY}

All datasets generated or analyzed during this study are included in the manuscript and/or the Supplementary Files.

\section{ETHICS STATEMENT}

This article does not contain any studies with human participants or animals performed by any of the authors.

\section{NOVELTY STATEMENT}

Impacts of soil co-inoculation with Glomus mosseae and Azotobacter chroococcumre on a plant on soil microbial dynamics and plant health has not been well known. In this study, native soil microbial population, nutrient uptake, and growth of onion plants have elucidated in a greenhouse pot experiment.

\section{REFERENCES}

1. Artursson, V., R.D. Finlay and J.K. Jansson, Interactions between arbuscular mycorrhizal fungi and bacteria and their potential for stimulating plant growth. Environ. Microbiol., 2006; 8: 1-10. https://doi.org/10.1111/ j.1462-2920.2005.00942.x

2. Dodd, J. The role of arbuscular mycorrhizal fungi in agro-and natural ecosystems. Outlook Agri., 2000; 29: 55-62. https://doi.org/10.5367/000000000101293059

3. Behl, R.K., S. Ruppel, E. Kothe and N. Narula, Wheat $x$ Azotobacter x VA Mycorrhiza interactions towards plant nutrition and growth-a review. J. Appl. Bot.Food Qual., 2012; 81: 95-109.

4. Germida, J. and F. Walley, Plant growth-promoting rhizobacteria alter rooting patterns and arbuscular mycorrhizal fungi colonization of field-grown spring wheat. Bio. Fert. Soils, 1996; 23: 113-120. https://doi. org/10.1007/BF00336050

5. Andrade, G., R. Azcon and G. Bethlenfalvay, A rhizobacterium modifies plant and soil responses to the mycorrhizal fungus Glomus mosseae. Appl. Soil Ecol., 1995; 2: 195-202. https://doi.org/10.1016/09291393(95)00054-O

6. Gryndler, M. and M. Vosatka, The response of Glomus fistulosum-maize mycorrhiza to treatments with culture fractions from Pseudomonas putida. Mycorrh., 1996; 6: 207-211. https://doi.org/10.1007/ s005720050128
7. Bethlenfalvay, G., G. Andrade and C. Azcon-Aguilar, Plant and soil responses to mycorrhizal fungi and rhizobacteria in nodulated or nitrate-fertilized peas (Pisum sativum L.). Bio. Fert. Soils, 1997; 24: 164-168. https://doi.org/10.1007/s003740050225

8. Olsson, P., E. Baath, I. Jakobsen and B. Soderstrom, Soil bacteria respond to presence of roots but not to mycelium of arbuscular mycorrhizal fungi. Soil Biol. Biochem., 1996; 28: 463-470. https://doi. org/10.1016/0038-0717(96)00011-9

9. Christensen, H. and I. Jakobsen, Reduction of bacterial growth by a vesicular-arbuscular mycorrhizal fungus in the rhizosphere of cucumber (Cucumis sativus L.). Biol. Fert. Soils, 1993; 15: 253-258. https://doi.org/10.1007/ BF00337209

10. Sharma, S.D., N. Sharma, C. Sharma, P. Kumar and A. Chandel, Glomus-Azotobacter symbiosis in apple under reduced inorganic nutrient fertilization for sustainable and economic orcharding enterprise. Sci. Hort., 2012; 146: 175-181. https://doi.org/10.1016/j. scienta.2012.08.027

11. Bagyaraj, D. and J. Menge, Interaction between a VA mycorrhiza and Azotobacter and their effects on rhizosphere microflora and plant growth. New Phytol., 1978; 80: 567-573. https://doi. org/10.1111/j.1469-8137.1978.tb01588.x

12. Behl, R.K., H. Sharma, V. Kumar and N. Narula, Interactions amongst mycorrhiza, Azotobacter chroococcum and root characteristics of wheat varieties. J. Agron. Crop Sci., 2003; 189: 151-155. https://doi.org/10.1046/j.1439-037X.2003.00026.x

13. Brown, M.E. and G. Carr, Interactions between Azotobacter chroococcum and vesicular arbuscular mycorrhiza and their effects on plant growth. J. Appl. Bacteriol., 1984; 56: 429-437. https://doi. org/10.1111/j.1365-2672.1984.tb01371.x

14. Mohamed, H.M. Effect of arbuscular mycorrhizal fungus Glomus mosseae and soil yeasts interaction on root nodulation, $\mathrm{N}$-fixation and growth of faba bean (vichia faba). Malaysian Journal of Soil Science, 2015; 19: 157-168.

15. Gerdemann, J.W, Nicolson, T.H. Spores of Mycorrhizal Endogone Species Extracted from Soil by Wet Sieving and Decanting. Transactions of the British Mycological Society, 1963; 46: 235-244. https://doi.org/10.1016/ S0007-1536(63)80079-0

16. Rajeshkumar, S., M.C. Nisha, P.C. Prabu, L. Wondimu and T. Selvaraj, Interaction between Glomus geosporum, Azotobacter chroococcum, and Bacillus coagulans and their Influence on Growth and Nutrition of Melia azedarach L. Turk. J.Biol., 2009; 33: 109-114.

17. Page AL, Miller RH, Keeny DR. Method of soil analysis. Part 1 Physical and Mineralogical Methods, Part 2. Chemical and Microbiological properties 2nd edn. Agronomy 9 ASA, SSSA, Madison. UAS, 1982.

18. McGonigle, T.P., Miller, M.H., Evans, D.G., Fairchild, D.L. and Swan, J.A. A new method which gives an objective measure of colonisation of roots by vesiculararbuscular mycorrhizal fungi, New Phytol., 1990; 115: 495-501 https://doi.org/10.1111/j.1469-8137.1990. tb00476.x 
19. Giovannetti, M., Mosse, B., An evaluation of techniques for measuring vesicular-arbuscular mycorrhizal infection in roots. New Phytol., 1998; 84: 489-500. https://doi.org/10.1111/j.1469-8137.1980.tb04556.x

20. Johnson, L.F. and E.A. Curl, Methods for research on the ecology of soil-borne plant pathogens. In: Methods for research on the ecology of soil-borne plant pathogens. Soil Biol. Biochem., 1972; 5: 47-81.

21. Hardy, R., R.C. Burns and R.D. Holsten, Applications of the acetylene-ethylene assay for measurement of nitrogen fixation. Soil Biol. Biochem., 1973; 5: 47-81. https://doi.org/10.1016/0038-0717(73)90093-X

22. Jackson M.L. Soil Chemical Analysis, Prentice Hall of India, New Delhi. India; 1973.

23. StatSoft, Statistica for Windows (Computer Program manual). StatSoft, Inc., Tulsa, OK, 1995.

24. Barea, J.M., M.J. Pozo, R. Azcon and C. Azcon Aguilar, Microbial interactions in the rhizosphere. Mol. Microb. Ecol. Rhizo., 2013; 1: 29-44. https://doi. org/10.1002/9781118297674.ch4

25. Klironomos, J. and M. Ursic, Density-dependent grazing on the extraradical hyphal network of the arbuscular mycorrhizal fungus, Glomus intraradices, by the collembolan, Folsomia candida. Bio. Fert. Soils, 1998; 26: 250-253. https://doi.org/10.1007/s003740050375

26. Sood, S. G., Chemotactic response of plant-growthpromoting bacteria towards roots of vesiculararbuscular mycorrhizal tomato plants. FEMS Microbiol. Ecol., 2003; 45: 219-227. https://doi.org/10.1016/ S0168-6496(03)00155-7

27. Meyer, J.R. and R. Linderman, Response of subterranean clover to dual inoculation with vesicular-arbuscular mycorrhizal fungi and a plant growth-promoting bacterium, Pseudomonas putida. Soil Biol. Biochem., 1986; 18: 185-190. https://doi.org/10.1016/00380717(86)90025-8

28. McAllister, C., I. Garcia Romera, J. Martin, A. Godeas and J. Ocampo, Interaction between Aspergillus niger van Tiegh. and Glomus mosseae.(Nicol. \& Gerd.) Gerd. \& Trappe. New Phytol., 1995; 129: 309-316. https:// doi.org/10.1111/j.1469-8137.1995.tb04301.x

29. El Shanshoury, A., Interactions of Azotobacter chroococcum, Azospirillum brasilense and Streptomyces mutabilis, in relation to their effect on wheat development. J. Agron. Crop Sci., 1995; 175: 119-127. https://doi.org/10.1111/j.1439-037X.1995. tb01137.x

30. Tilak, K., A. Dwivedi and C. Li, Enhancement of spore germination of Glomus fasciculatum by bacterial cell free extracts. Ind. J. Exp. Biol., 1990; 28: 373-375.

31. Manske, G., Enhancement of mycorrhizal (AMF) infection, nutrient efficiency and plant growth by Azotobacter chroococcum in wheat. Evidence for varietal effects. In: Narula N. (ed.): Azotobacter in sustainable agriculture. CBS Publ. Distrib., New Delhi, 1998; 136-147.

32. Tsavkelova, E., S.Y. Klimova, T. Cherdyntseva and A. Netrusov, Microbial producers of plant growth stimulators and their practical use: a review. Appl. Biochem. Microbiol., 2006; 42: 117-126. https://doi. org/10.1134/S0003683806020013

33. Wu, S., Z. Cao, Z. Li, K. Cheung and M. H. Wong, Effects of biofertilizer containing $\mathrm{N}$-fixer, $\mathrm{P}$ and $\mathrm{K}$ solubilizers and AM fungi on maize growth: a greenhouse trial. Geoderma., 2005; 125: 155-166. https://doi. org/10.1016/j.geoderma.2004.07.003

34. Yousefi, A.A., K. Khavazi, A.A. Moezi, F. Rejali and H.A. Nadian, Phosphate solubilizing bacteria and arbuscular mycorrhizal fungi impacts on inorganic phosphorus fractions and wheat growth. World Appl. Sci. J., 2011; 15: 1310-1318.

35. Vafadar, F., R. Amooaghaie and M. Otroshy, Effects of plant-growth-promoting rhizobacteria and arbuscular mycorrhizal fungus on plant growth, stevioside, NPK, and chlorophyll content of Stevia rebaudiana. J. Plant Interact., 2014; 9: 128-136. https://doi.org/10.1080/ 17429145.2013.779035

36. Kumar, A., S. Sharma and S. Mishra, Evaluating effect of arbuscular mycorrhizal fungal consortia and Azotobacter chroococcum in improving biomass yield of Jatropha curcas. Plant Biosys., 2016; 150: 10561064. https://doi.org/10.1080/11263504.2014.1001 001 